Brief scientific paper

UDK 621.313.5.025.4:629.125.12.034

doi: 10.5767/anurs.cmat.110202.en.185P

\title{
STUDYING THE CHARACTERISTICS OF DISCHARGE LAMPS FOR OPERATION IN NAVIGATION LIGHTHOUSES SUPPLIED BY PHOTOVOLTAIC SYSTEMS
}

\author{
S. Platikanov ${ }^{*}, P$. Tsankov \\ Technical University of Gabrovo, Faculty of Electrical Engineering and Electronics \\ 4 Hadji Dimitar Str., 5300 Gabrovo, Bulgaria
}

\begin{abstract}
Summary: This paper presents the results of the research done on the start-up process of discharge lamp ignition up to the transition into a steady-state regime of operation. The paper studies the change in the basic electrical characteristics: current, voltage, power, power factor, as well as the change in the luminous flux. Different operation circuits of the lamps are discussed: from the mains supply with and without a compensating capacitor. Conclusions have been drawn about this initial period in the ignition of discharge lamps and their application and possibilities of use in navigation lighthouses supplied by photovoltaic systems.

Keywords: discharge lamp, navigation lighthouse, photovoltaic system, electrical characteristics, luminous flux, luminous efficacy.
\end{abstract}

\section{INTRODUCTION}

In view of studying the possibilities of metal halide lamps as a light source for navigation lighthouses supplied by photovoltaic system, their major characteristics have been examined:

- testing ignition, start-up process up to a steady-state regime;

- testing the lamp parameters in case of change in the mains AC voltage.

\section{ESTABLISHING AN EXPERIMENTAL SETUP FOR THE MEASUREMENTS}

As a result of the choice of an electric circuit for performing the measurements, the selection and the delivery of suitable light sources, chokes, ignition devices [1], capacitors for PF correction, mains voltage $220 \mathrm{~V}$ AC and modern instrumentation for electrical and light equipment measurements, the following electric circuit is proposed - Figure 1 .

The programmable electrical energy analyzer PROWATT-3 (CHAUVIN ARNOUX) is a configurable instrument and parameters can be selected and entered into a chosen test program. This enables subsequent recall, via the RS-232-C port, to a printer or microcomputer. The PROWATT software product "CA ANALYSE WATT" allows different graphs to be plotted using the data stored in the PROWATT.
The results of the tests are presented in Figures 2 to 8 .

The following symbols have been used in the text:

$\mathrm{U}_{\mathrm{S}}$ - mains voltage $220 \mathrm{~V} \mathrm{AC}, 50 \mathrm{~Hz}, \mathrm{~V}$

$\mathrm{I}_{\mathrm{S}}$ - mains (source) current, $A$

$\mathrm{I}_{\mathrm{L}}$ - lamp current, $A$

$\mathrm{U}_{\mathrm{L}}$ - lamp voltage, $V$

$\mathrm{P}$ - active power consumption from the mains

for the whole circuit, $W$

$\mathrm{P}_{\mathrm{L}}$ - active power consumption by the lamp, $W$

$\mathrm{Q}$ - reactive power, $V A r$

$\mathrm{S}$ - apparent power, $V A$

$\Phi$ - luminous flux, in relative units

$\mathrm{PF}$ - power factor, $\cos \varphi$

\section{STUDIES OF RUN-UP CHARACTERI- STICS OF DISCHARGE LAMPS}

Figure 2 and Figure 3 show the testing of the start-up process of the metal halide lamp HQI-T 250 W/D - from ignition up to the transition into a steady-state regime $[2,3]$. Figure 3 is realized with the connected capacitor for PF correction, and Figure 2 - without a capacitor. The changes in current $\mathrm{I}_{\mathrm{S}}$, active power $\mathrm{P}$, power factor PF, luminous flux $\Phi$ have been presented. The data from the measurements are a result of the incorporated programmable 
analyser PROWATT - 3 and have been computer processed using its software product CA ANALYSE WATT and Microsoft Excel.

The current $\mathrm{I}_{\mathrm{S}}$ (in the circuit without a capacitor) exceeds the steady-state value by 152 seconds (about 2.5 minutes) - Figure 2, Table 1. In both cases the steady-state regime sets in finally $3.5 \div 4$ minutes after start-up. The experience from the tests shows that these types of lamps do not always take the same time for ignition after start up. During the first 3 or 4 seconds there are some fluctuations, but after the final ignition, the start-up process develops in the same way.
The compensation of the reactive power in the operation circuit of the lamp in the navigation lighthouse is required in order to guarantee rational loading of the power supply source and the mains, which is achieved by means of the capacitor for $\mathrm{PF}$ correction C [4].

When comparing the results obtained from testing a metal halide lamp HQI-T $250 \mathrm{~W} / \mathrm{D}$ presented in Figure 3 - with a capacitor for PF correction $\mathrm{C}$, and Figure 2 - without a capacitor for PF correction $\mathrm{C}$, after the steady-state regime has been established, the following values have been obtained:

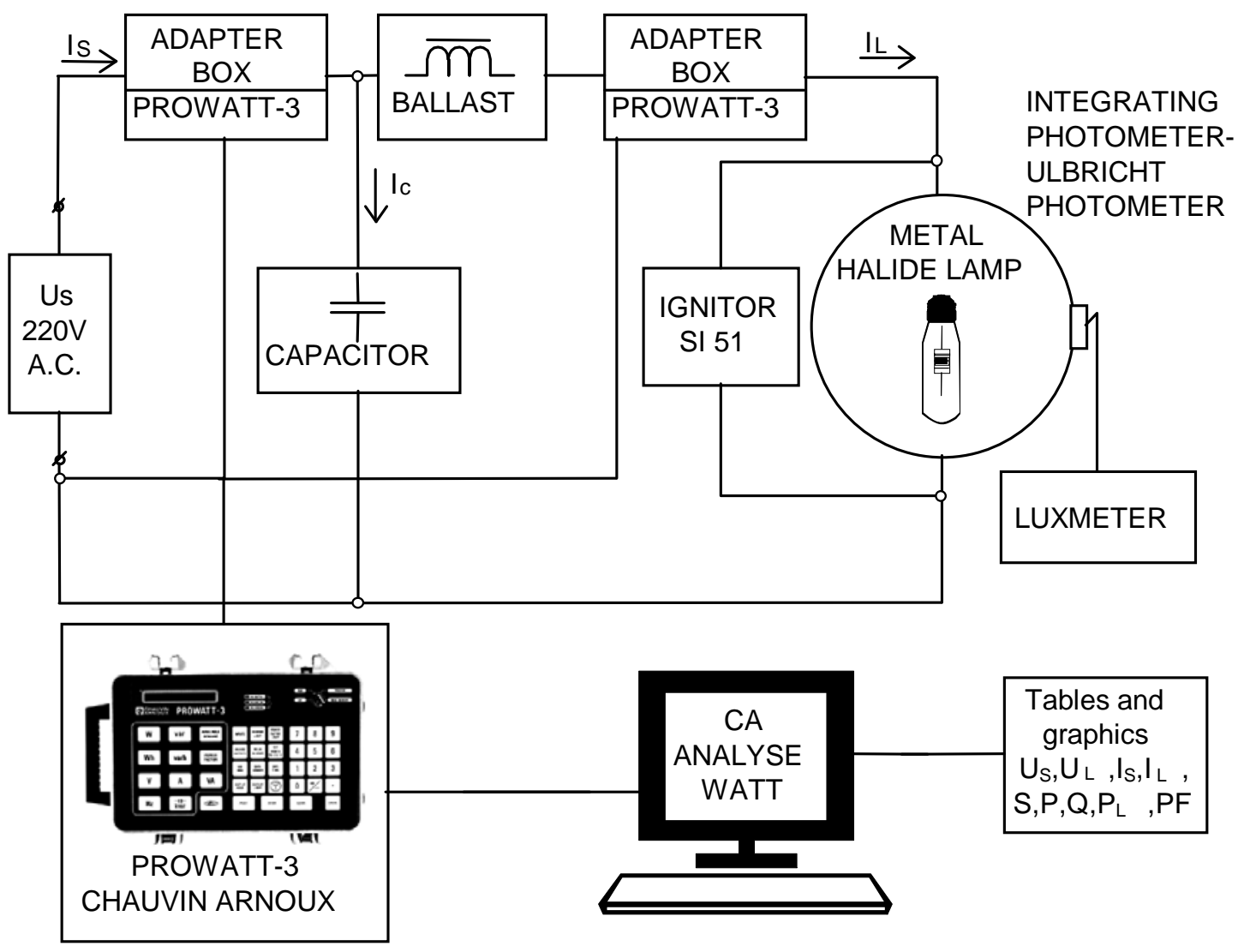

Figure 1. Experimental setup for the measurements

Table 1. Current, active power, power factor with capacitor and without capacitor

\begin{tabular}{|l|c|c|c|}
\cline { 2 - 4 } \multicolumn{1}{c|}{} & $\mathrm{I}_{\mathrm{S}}, A$ & $\mathrm{P}, W$ & $\mathrm{PF}$ \\
\hline Figure 3 - with a capacitor & 1.29 & 278.60 & 0.951 \\
\hline Figure 2 - without a capacitor & 2.90 & 270.89 & 0.421 \\
\hline
\end{tabular}




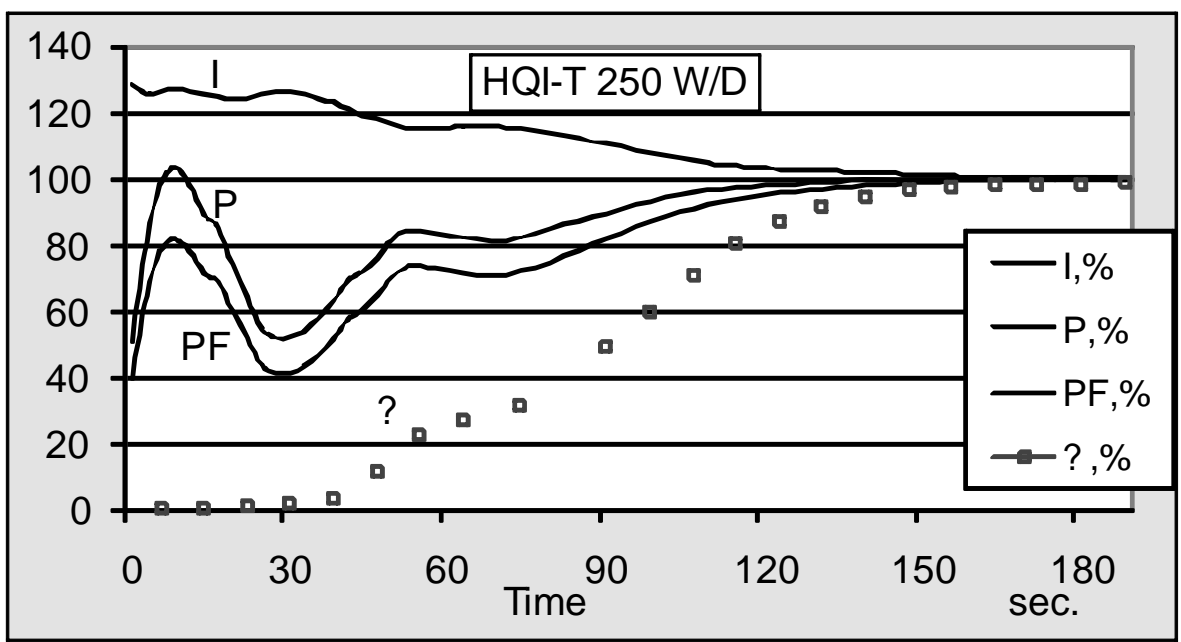

Figure 2. Run-up characteristics of current $I_{S}$, power $P$, power factor $P F$ and luminous flux $\Phi$ for a metal halide lamp HQI-T 250 W/D without a capacitor for PF correction.

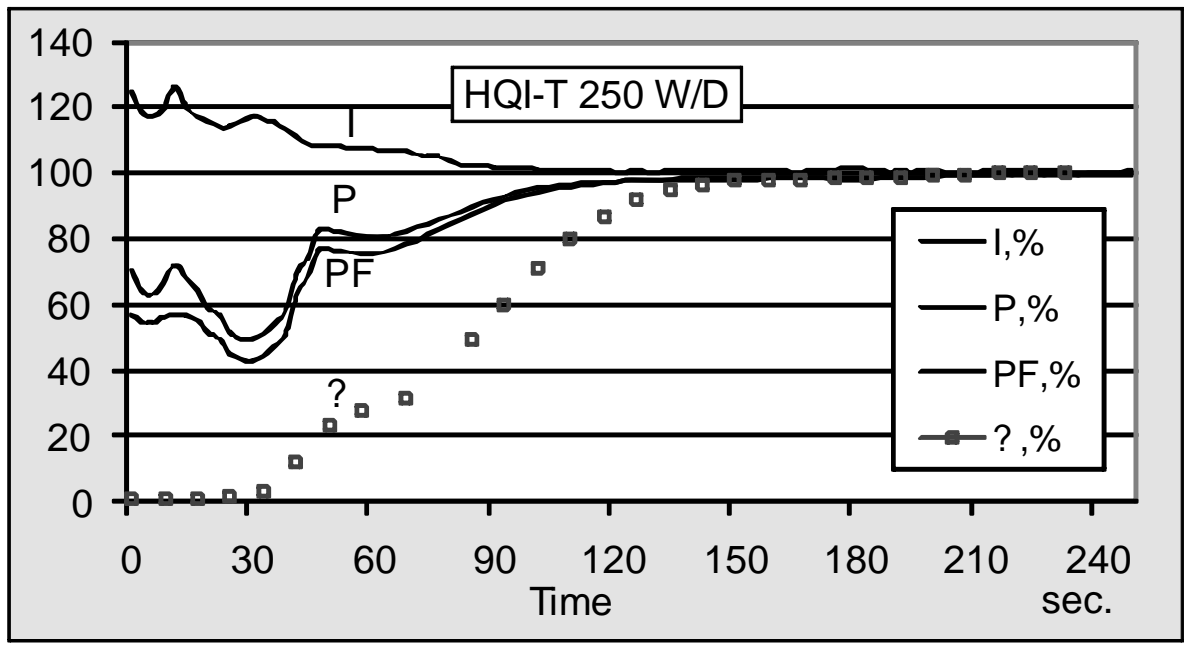

Figure 3. Run-up characteristics of current $I_{S}$, power $P$, power factor $P F$ and luminous flux $\Phi$ for a metal halide lamp HQI-T 250 W/D with a capacitor for PF correction.

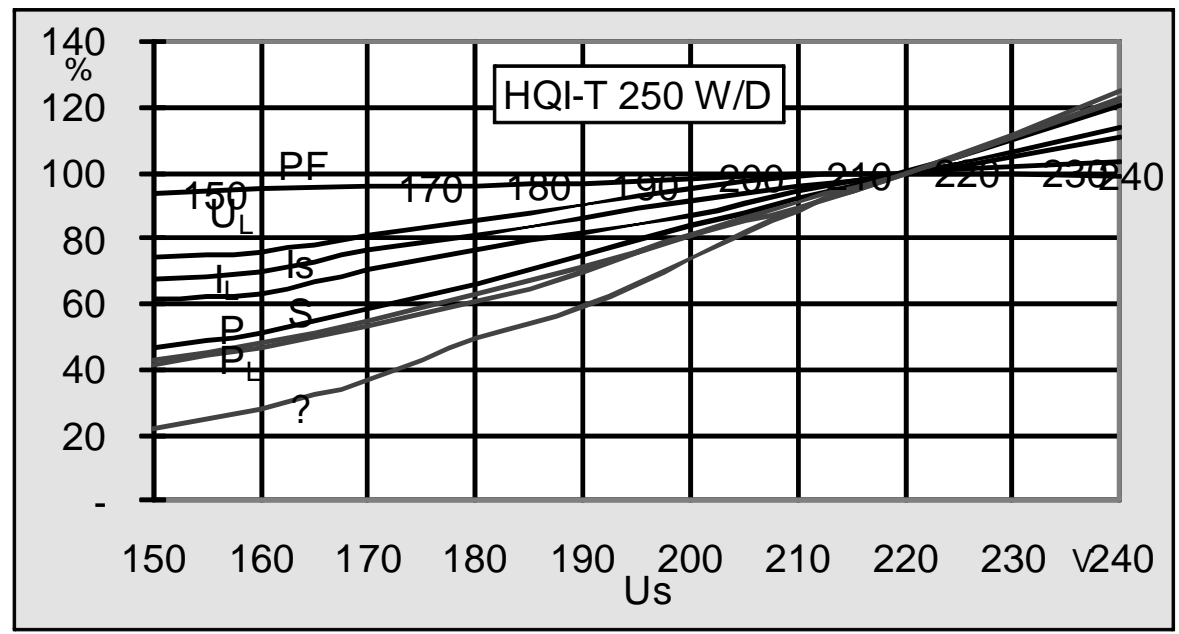

Figure 4. Influence of mains voltage variations on the lamp current $I_{L}$, current $I_{S}$, lamp power $P_{L}$, power $P$, power $S$, lamp voltage $U_{L}$, luminous flux $\Phi$ and power factor $P$ 


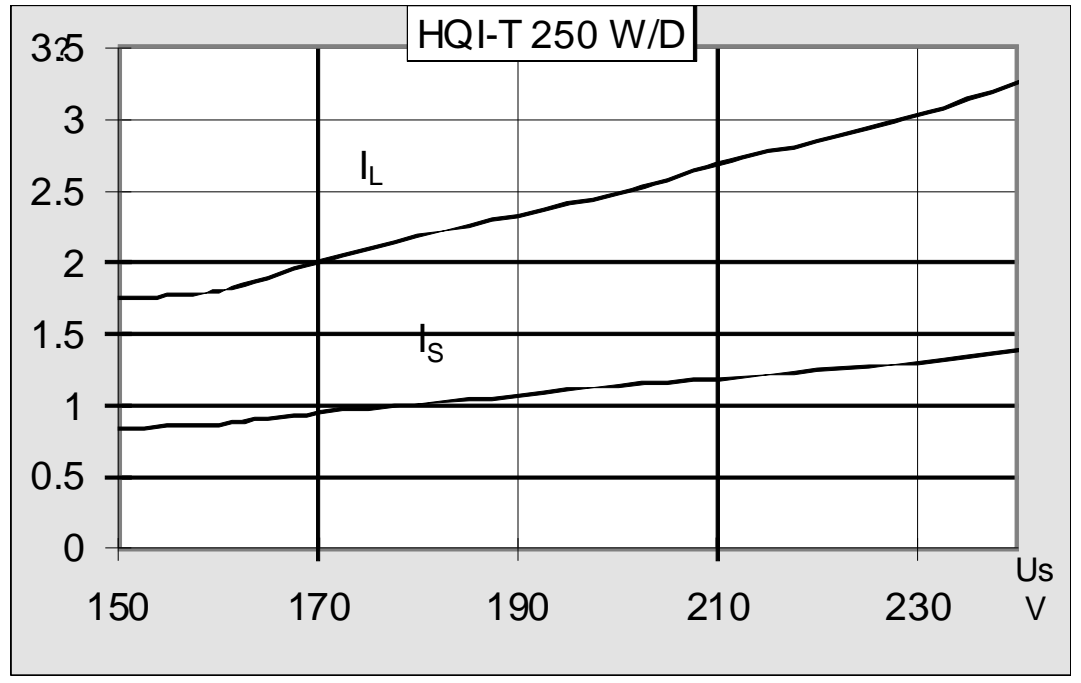

Figure 5. Influence of mains voltage variations on the lamp current $I_{L}$ and current $I_{S}$.

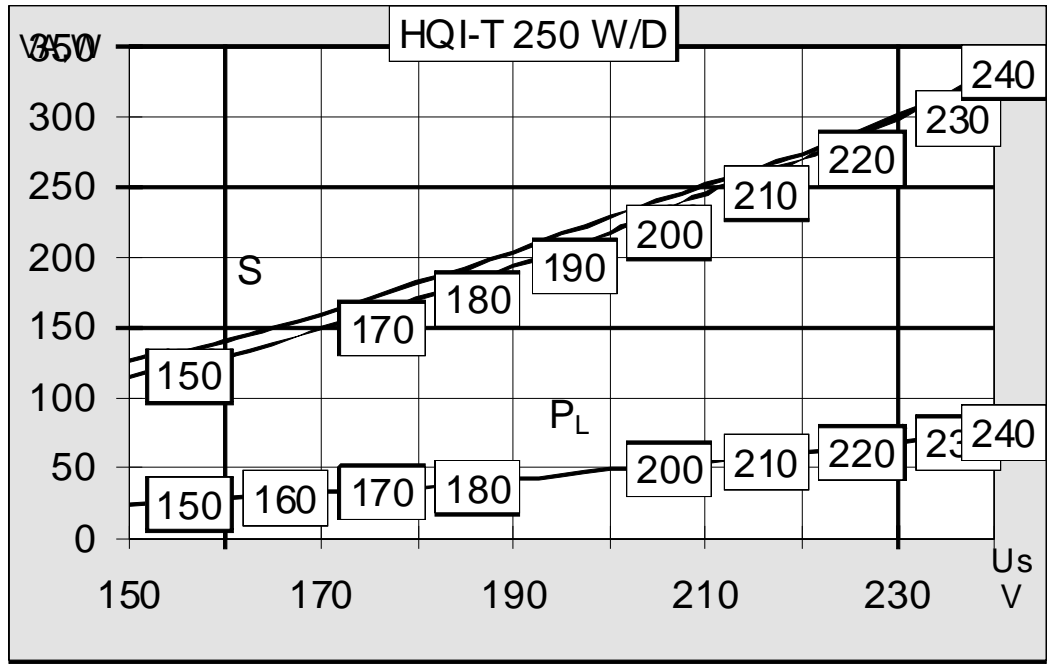

Figure 6. Influence of mains voltage variations on the, lamp power $P_{L}$, power $P$, power $S$.

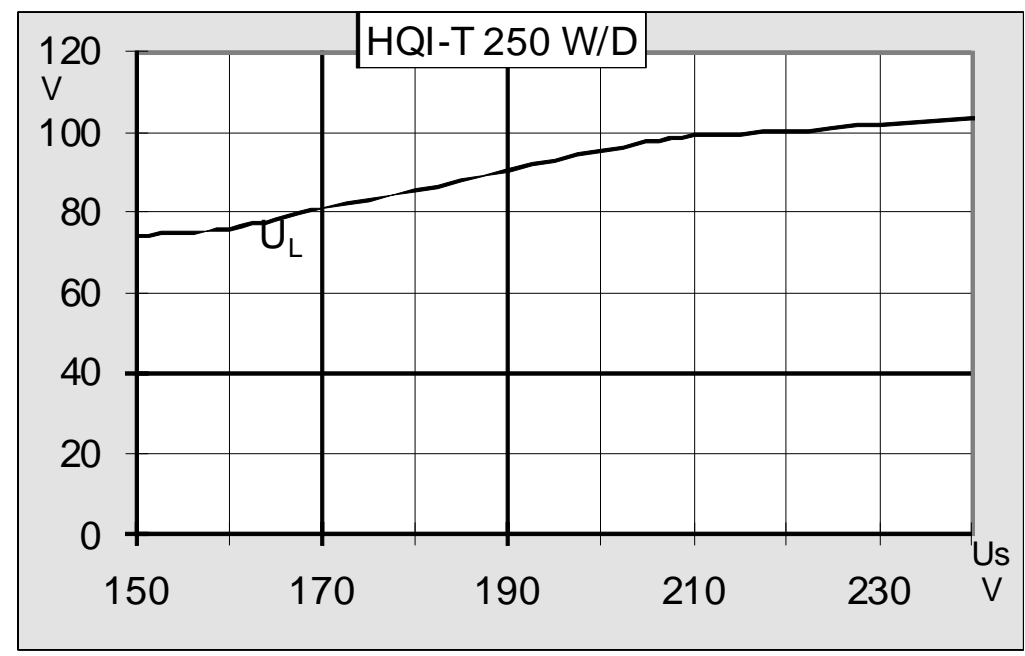

Figure 7. Influence of mains voltage variations on the lamp voltage $U_{L}$. 


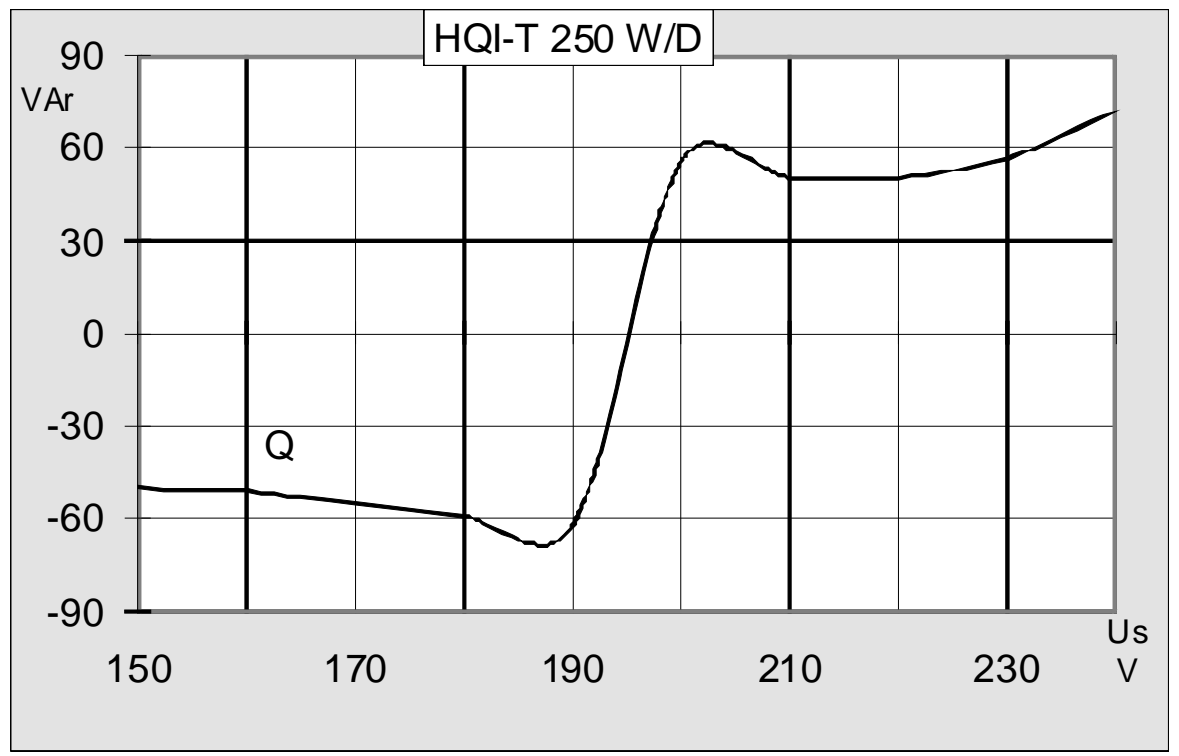

Figure 8. Influence of mains voltage variations on the reactive power $Q$.

When the lamp operates in a circuit without a capacitor for PF correction, the current consumed by the whole circuit is $I_{S}=2.90 \mathrm{~A}$, which is twice as much as the value $\mathrm{I}_{\mathrm{S}}=1.29 \mathrm{~A}$, when the calculated capacitor $\mathrm{C}$ is connected. The power factor is 0.951 (close to 1) with a compensated circuit, and 0.421 with an uncompensated circuit. Having in mind the purpose of these tests for the use of a metal halide lamp in navigation lighthouses with power supply from a set of PV panels, and in view of the economical low-consumption power supply, it is essential to use a capacitor for PF correction in the lamp circuit. As it can be seen, in the case of a steady-state regime and $\mathrm{U}_{\mathrm{S}}=220 \mathrm{~V}$, the total power consumption $\mathrm{S}$ is approximately equal to the active power $\mathrm{P}$, since the reactive power $\mathrm{Q}$ is compensated by the capacitor for PF correction (Figure 6). Figures 4, 5, 6, 7 and 8 present the dependence of all tested lamp parameters on the change in the supply voltage $\mathrm{U}_{\mathrm{S}}$.

Figure 4 presents the change in $\mathrm{I}_{\mathrm{S}}, \mathrm{I}_{\mathrm{L}}, \mathrm{U}_{\mathrm{L}}, \mathrm{S}, \mathrm{P}$, $\mathrm{P}_{\mathrm{L}}, \mathrm{PF}$ and $\Phi$, expressed in percentage, in a common coordinate system, depending on the change in $U_{S}$ from $240 \mathrm{~V}$ to $150 \mathrm{~V}$, when the lamp is finally turned off. There is a capacitor for PF correction connected to the electric circuit.

Figure 4 shows a considerable decrease in the luminous flux $\Phi$ by $25 \%$, when the supply voltage $\mathrm{U}_{\mathrm{S}}$ decreases by $10 \%$, i.e. from $220 \mathrm{~V}$ to $200 \mathrm{~V}$ [5]. This should probably not be allowed, since it will sharply deteriorate the visibility of navigation lighthouses.
The decrease in luminous flux is due to the change of luminous efficacy $(\mathrm{lm} / \mathrm{W})$ as a result of the reduced value of the lamp current $\mathrm{I}_{\mathrm{L}}$. When the supply voltage drops by $10 \%$, the lamp power consumption decreases by $20 \%$ (Figure 4 ).

Figures 5, 6, 7 and 8 present the change in $\mathrm{I}_{\mathrm{S}}$, $\mathrm{I}_{\mathrm{L}}, \mathrm{S}, \mathrm{P}, \mathrm{P}_{\mathrm{L}}, \mathrm{U}_{\mathrm{L}}, \mathrm{Q}, \Phi, \mathrm{PF}$ for the tested lamp HQI-T $250 \mathrm{~W} / \mathrm{D}$ with their real values measured by means of PROWATT - 3, when $\mathrm{U}_{\mathrm{S}}$ changes from $240 \mathrm{~V}$ to $150 \mathrm{~V}$. The interesting results obtained, which are not published in the catalogues of the manufacturing firms, are suitable both for explaining the lamp operation mode according to its supply voltage $\mathrm{U}_{\mathrm{S}}$, and for studying its joint operation with an inverter, when powered by PV solar panels. It can be seen from Figure 7 that when $\mathrm{U}_{\mathrm{S}}=220 \mathrm{~V}, \mathrm{U}_{\mathrm{L}}=100 \mathrm{~V}$, i.e. $\mathrm{U}_{\mathrm{L}} / \mathrm{U}_{\mathrm{S}}=0.45$. The value of $\mathrm{U}_{\mathrm{L}} / \mathrm{U}_{\mathrm{S}}=0.45-0.7$ is limited from below by the economic characteristics of the lamp - ballast circuit, and from above - by the sharp deterioration of the discharge lamp stability of operation. When $U_{L} / U_{S}$ decreases, the loss proportion in the lamp increases, as well as the mass and dimensions of the ballast and power loss in it.

It can be concluded from Figure 4 that the luminous flux $\Phi$ and the power factor PF rise more or less steadily with the change in $\mathrm{U}_{\mathrm{S}}$ from $150 \mathrm{~V}$ to $240 \mathrm{~V}$, the power factor being equal to 0.95 $(\mathrm{PF}=0.95)$ when $\mathrm{U}_{\mathrm{S}}=220 \mathrm{~V}$. 


\section{CONCLUSION}

The light engineering characteristics of metal halide lamps are largely superior to the characteristics of incandescent lamps, which so far have found application only in the existing navigation lighthouses. One of the main comparative factors is the luminous efficacy which is $10-20 \mathrm{Im} / \mathrm{W}$ for the incandescent lamps, and $70-95 \mathrm{~lm} / \mathrm{W}$ for the metal halide lamps. This means that the power consumption necessary for the luminous flux emitted by the navigation lighthouse will be several times smaller. This is essential for concrete application of metal halide lamps in navigation lighthouses supplied by photovoltaic systems.

\section{REFERENCES}

[1] Component Systems for Lighting Applications, Vossloh-Schwabe Deutschland $\mathrm{GmbH}$, Lüdenscheid, 2008.

[2] R. Baer, M. Eckert, B. Gall, R. Schnor, Beleuchtungstechnik: Grundlagen, Verlag Technik,HUSS-MEDIEN GmbH, Berlin, 1990.

[3] C. Strum, E. Klein, Betriebsgeräte und Schaltungen für elektrische Lampen, Siemens Aktiengesellschaft, Berlin, 1992.

[4] Handbuch für Beleuchtung 4, Cornelsen Verlag GmbH, 1994.

[5] High Intensity Discharge Lamp Ballasts, Philips Lighting Electronics, 2009.

$\operatorname{son} 2$

\section{ПРОУЧАВАЬЕ КАРАКТЕРИСТИКА СВЈЕТИЉКИ СА ПРАЖЬЕЬЕМ ЗА РАД У НАВИГАЦИОНИМ СВЈЕТИОНИЦИМА КОЈИ СЕ НАПАЈАЈУ ИЗ ФОТОНАПОНСКИХ СИСТЕМА}

Сажетак: У овом раду приказани су резултати истраживања проведеног на поступку покретања паљења свјетиљке са пражњењем до прелаза на стални режим рада. У раду се изучава промјена основних електричних карактеристика: струје, напона, снаге, фактора снаге као и промјена свјетлосног тока. Обрађена су различита радна кола свјетиљки: од мрежног напона са и без компензујућег кондензатора. Изведени су закључци о овом почетном периоду паљења свјетиљки са пражњењем и њиховој примјени и могућности употребе у навигационим свјетионицима напајаним фотонапонским системима.

Кључне ријечи: свјетиљка с пражњењем, навигациони свјетионик, фотонапонски систем, електричне карактеристике, свјетлосни флукс, свјетлосна ефикасност. 